\title{
Extent of Adoption of Paddy Seed Production Practices by the Farmers of Davanagere District, India
}

\author{
B. M. Chetan ${ }^{2 *}$, Ramappa Patil ${ }^{1}$, Basavaraj Beerannavar ${ }^{2}$, \\ H. G. Sannathimappa ${ }^{3}$ and H. B. Mallikarjun ${ }^{2}$ \\ ${ }^{1}$ Station EEU AHRS Kathalagere, India \\ ${ }^{2}$ Department of Agriculture Extension, ${ }^{3}$ Department of Agronomy, College of Agriculture, \\ UAHS, Shivamogga, Karnataka, India \\ *Corresponding author
}

\section{A B S T R A C T}

Keywords

Paddy Seed

Production, farmers

knowledge,

situational factors

Article Info

Accepted:

24 October 2020

Available Online:

10 November 2020
The present study was carried out in Davanagere district of Karnataka state during the year 2018-19 to know theextent of Adoption of Paddy Seed Production Practices by the farmers of Davanagere district. A total sample consisting of 120 respondents from four major paddy seed producing taluks of the district were selected wherein three villages from each taluk and ten farmers from each village were interviewed using pre- tested interview schedule. More than half of the farmers had medium $(65.84 \%)$ to high $(21.66 \%)$ adoption level with respect to overall adoption of paddy seed production practices.most of them has adopted the practices like land preparation and transplanting, maintenance of proper seed rate, rouging and harvesting / post-harvest operations etc. Hence, seed certification agencies should provide adequate training to the paddy seed production farmers to enhance their level of adoption of paddy seed production technologies.

\section{Introduction}

Rice is an important food crop for more than one third of the world's population. Globally rice occupies an area of $161.1 \mathrm{~m}$ ha with a production of $716.7 \mathrm{mt}$ and the productivity of $4448 \mathrm{~kg} \mathrm{ha}^{-1}$ Ninety five per cent of the world's rice is grown in developing countries, primarily in Asia, Africa and Latin America. China and India are the largest rice producing and consuming countries in the world.

Quality seed is an important input for increasing agricultural productivity.
Appreciating its pivotal role in meeting the challenges posed by increasing population, the Indian government initiated various policy measures which contributed in the growth of seed industry in India. From a few units there has been a tremendous rise (more than 200 seed companies in private sector) in number of seed companies and corporations. Quality seed production of 380.29 lakh quintals in 2016- 17 and 419.41 lakh quintals in 2017-18, 55 per cent was produced by Government agencies and 50 per cent by private seed companies (Anonymous, Ministry of Agriculture 23 may, 2017).In India quality 
seed production is a risky venture as there is always a chance of rejection at the certification stage. The institutional sources have not fully appreciated the need for higher scale of finance for seed production. Also, there is no insurance for seed crop production. The concept of seed village is not new. One of the tasks was to educate and train the farmers about its high yielding capacity. The improved variety yielded almost double than the paddy varieties available at that time. This generated a great demand for paddy seed.

Being considered paddy seed production as one of the premier technology in paddy production and also having included many intricacies in understanding and application of paddy seed production technology, it is the high time to gauge the psychological perspectives of farmers on paddy seed production technology. There is also a need for an objective analysis of adoption of paddy seed production practices in paddy seed production.

\section{Materials and Methods}

The district comprises of six taluksviz., Davanagere, Honnali, Harapanahalli, Chennagiri, Jagalur and Harihara. Only four taluks selected i.e., Davanagere, Honnali, Harapanahalli, and Harihara based on highest paddy seed production area. From each taluk, three villages and from each village, 10 farmers engaged in seed production since from last three years were randomly selected as respondents for the study. Thus the sample size of the study comprises of 120 respondents and data was collected from the respondents through personal interview method by using structured interview schedule.

Adoption is a decision to make full use of an innovation as a best course of action available. In this study, it refers to the adoption of paddy seed production practices were listed. A total number of 17 questions from land preparation up to harvesting were listed by consulting with experts and were the responses were quantified by giving 1 and 0 scores for adopted and not adopted respectively for each of the practice. Thus, the maximum and minimum score that the respondent can score is 17 and 0 .

Based on total score obtained for the 17 paddy cultivation practices by the respondents, the paddy seed production farmers were grouped into low, medium and high using mean and standard deviation as a measure of check.

\section{Results and Discussion}

The adoption of paddy seed production practices depends on various factors such as farmers knowledge, situational factors, extent of support of change agent efforts, personal and socio-psychological characteristics of farmers, the characteristics of innovation itself, complexity of practices, timely availability of inputs etc. However, it is true that all the recommended practices will not be adapted to a level of degree by all the members in a given social system. The findings of the present study are also in line with this fact with respect to adoption of paddy seed production practices by the respondents which are presented in Table 1 indicated that as high 65.84 as per cent came under medium adopter group followed by 21.66 percentage of the respondents belonged to high adoption group. Majority of the respondents comes under medium to high adoption category since most of them has adopted the practices like land preparation and transplanting, maintenance of proper seed rate, rouging and harvesting / post-harvest operations etc.. The obtained results may be due to the fact that, if the farmers did not adopt these seed production practices, there is 
a chance of rejection their entire lot due to low quality.

Least percentage of respondents $(12.50 \%)$ belonged to low overall adoption level. This could be due to lack of proper knowledge on some seed production practices, lack of technical guidance could be the reason for non-adoption, even though farmers had enough knowledge, difficulty in adopting some practices like maintaining isolation distance from other field and lack of contact with extension personnel may have resulted in lower overall adoption level of paddy seed production farmers with respect to some of the paddy seed production practices.

Table.1 Overall adoption level of paddy seed production farmers $(n=120)$

\begin{tabular}{|c|c|c|c|}
\hline \multirow{2}{*}{ Particulars } & Criteria & \multicolumn{2}{|c|}{ Respondents } \\
\cline { 2 - 4 } & & Frequency & Percentage \\
\hline Low & $<($ Mean - SD) & 15 & 12.50 \\
\hline Medium & (Mean \pm SD) & 79 & 65.84 \\
\hline High & $>($ Mean + SD) & 26 & 21.66 \\
\hline & & Mean $=11.25$ & S.D $=1.69$ \\
\hline
\end{tabular}

Table.2 Activity wise adoption of recommended paddy seed production practices by the by the farmers $(n=120)$

\begin{tabular}{|c|c|c|c|c|c|}
\hline \multirow{3}{*}{$\begin{array}{l}\text { Sl. } \\
\text { No. }\end{array}$} & \multirow{3}{*}{$\begin{array}{c}\text { Paddy seed production } \\
\text { activities }\end{array}$} & \multicolumn{4}{|c|}{ Respondents } \\
\hline & & \multicolumn{2}{|c|}{ Adopted } & \multicolumn{2}{|c|}{ Not adopted } \\
\hline & & Frequency & Percent & Frequency & Percent \\
\hline 1 & $\begin{array}{l}\text { Land preparation and } \\
\text { Transplanting }\end{array}$ & 110 & 91.66 & 10 & 8.34 \\
\hline 2 & Seed rate & 116 & 96.66 & 4 & 3.34 \\
\hline 3 & Seed treatment & 20 & 16.66 & 100 & 83.34 \\
\hline 3 & Plant protection disease/pest. & 72 & 60.00 & 48 & 40.00 \\
\hline 4 & $\begin{array}{l}\text { Nutrient Management/FYM } \\
\text { application }\end{array}$ & 55 & 45.84 & 65 & 54.16 \\
\hline 5 & Rouging & 115 & 95.84 & 5 & 4.16 \\
\hline 6 & Harvesting /Post harvesting & 110 & 91.66 & 10 & 8.34 \\
\hline
\end{tabular}

The result presented in Table 2 represents level of adoption behaviour such as adoption and non-adoption, as per individual recommended paddy seed production practices. The results are presented practice wise in the following paragraphs.

More than 90 per cent of seed production farmers were fully adopted land preparation and transplanting, seed rate, rouging and harvesting / post harvesting practices. These are the basic practices and need to be carried out by every seed production farmers, if these practices were not followed there may be chance of not getting the product to the level of seed production standards hence the respondents opted. 60.00 per cent and 45.84 per cent of farmers were adopted plant protection disease/ pest and nutrient management practices, respectively. Less than twenty (16.66 \%) per cent of seed production farmers were only adopted seed treatment because these respondents were of the 
opinion that the foundation seeds supplied to them were already treated by the suppliers hence not adopted.

Recommended nutrient management practices like application of NPK 40:20:20 kg/ acre, 2-3 tones/acre of FYM etc. were not adopted and also they didn't adopt isolation distance of 3 mts from other field. The reason for their poor adoption may be due to lack of sufficient technical guidance on those above practices, apart from requiring costly inputs and difficulty in adopting some practices.

The state agriculture university and state department of agriculture should organise need based skill oriented training programmes especially through KVKs and other institutes to hasten up the adoption of these practices.

The farmers have adopted recommended seed production practices such as land preparation and transplanting, seed rate, rouging and harvesting /post-harvest practices. While some of the farmers have not adopted the practices like plant protection measures, nutrient management and seed treatment.

Hence, Karnataka State Seed Corporation Ltd (KSSC), National Seed Corporation Ltd (NSC) and AHRS Kathalagere have the responsibility to motivate the farmers to adopt the practices mentioned above.

In conclusion the results of the research study revealed that the paddy seed production farmers have adopted recommended seed production practices such as land preparation and transplanting, seed rate, rouging and harvesting /post-harvest practices. While some of the farmers have not adopted the practices like plant protection measures, nutrient management and seed treatment. Hence, Karnataka State Seed Corporation Ltd (KSSC), National Seed Corporation Ltd (NSC) and AHRS Kathalagere have the responsibility to motivate the farmers to adopt the practices mentioned above.

\section{References}

Aldas Janaiah and Fangming XIE., 2010. Hybrid rice adoption in India: farm level impacts and challenges Technical bulletin no.14.IRRI.

Atar, R.S. 2012, Study on knowledge and adoption of recommended grape cultivation practices by the grape growers. M.Sc. (Agri.) Thesis, submitted to MKV, Parbhani.

Krunal Kumar C. V., 2015, Technologies gap in adoption of recommended maize seed production practices by the maize seed producers in Dathod district of Gujarat state M.Sc. (Agri.) Thesis, (unpublished), submitted to AAU, Anand.

Mustapha, S.B., Undiandeye, U.C., Sanusi, A.M and Bakari, S. 2012.Analysis of adoption of improved rice production technologies in Jeer local government area of Borno state, Nigeria. International Journal of Development and Sustainability Online ISSN: 2168-8662 - www.isdsnet.com/ijds Volume 1 Number 3: Pages1112-1120.

Praveen R., 2014, A study on knowledge and adoption levels of paddy farmers in East Godavari District of Andhra Pradesh. M.Sc. (Agri.) Thesis, ANGRAU, Hyderabad.

Umar, S.I., Ndanitsa, M.A and Olaleye, S.R., 2009, Adoption of improved rice production technologies among youth farmers in Gbako Local Government Area, Niger State. Journal of Agricultural Extension.Vol.13(1).

\section{How to cite this article:}

Chetan, B. M., Ramappa Patil, Basavaraj Beerannavar, H. G. Sannathimappa and Mallikarjun, H. B. 2020. Extent of Adoption of Paddy Seed Production Practices by the Farmers of Davanagere District. Int.J.Curr.Microbiol.App.Sci. 9(11): 3658-3661. doi: https://doi.org/10.20546/ijcmas.2020.911.439 